68

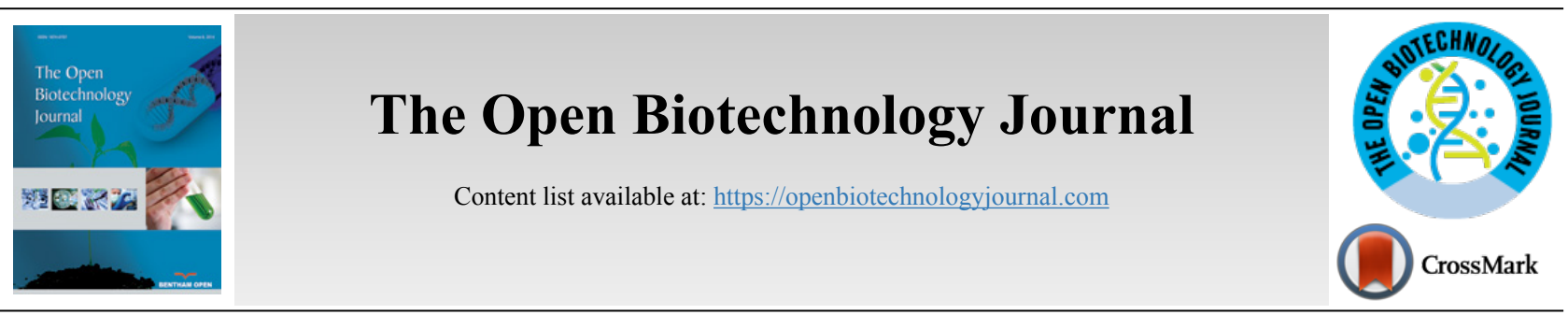

$(', 725, \$ /$

\title{
Editorial: Micropollutants in the Environment: Challenges and Bioremediation Strategies
}

\author{
Sanket J. Joshi ${ }^{1, *}$ and Hemen Sarma ${ }^{2, *}$ \\ ${ }^{\prime}$ Oil \& Gas Research Centre, Central Analytical and Applied Research Unit, Sultan Qaboos University, Oman \\ ${ }^{2}$ Department of Botany, N.N. Saikia College, Titabar, Jorhat, Assam, India
}

Over the years, the load of inorganic and organic micropollutants in the environment has significantly increased, threatening our daily lives. Chemicals used in agriculture, industries, and power generation, as well as wastewater treatment and medical technology, are some of the major polluters [1]. Though the use of recycled wastewater is increasing, there are concerns about human health and environmental impacts related to the presence of biologically active micropollutants that could cause side effects, such as genetic damage, mutations, and cancer [2, 3]. The risks of environmentally derived micropollutants to ecosystems and human health are still not fully understood [4]. Pollution monitoring is the quantitative or qualitative assessment of the occurrence, consequence, or concentration of any polluting substance in a defined environment. Accurate measurements are required to generate reliable data for forecasting and managing pollution risks [5]. The biological tools available for monitoring environmental pollution are based on biomarkers that are typically indigenous to the site of investigation and have been exposed to local environmental conditions over extended periods of time. A biomarker is a biological response measured in an organism that is naturally exposed to a study site that serves as an indicator of the presence and effect of environmental pollutants. The quantitative, sensitive, and specific biological response to be quantified is ideal [6]. Through the broad biodegradation capabilities developed by microorganisms towards undesirable organic compounds, bioremediation may be used to restore contaminated soils [7, 8]. Recent advancements in bioremediation techniques over the last two decades have focused on the critical goal of successfully restoring polluted environments in an economically and environmentally friendly manner. Diverse bioremediation techniques have been developed to rehabilitate polluted environments. Bioremediation can be carried out using

\footnotetext{
* Address correspondence to these authors at the Oil \& Gas Research Centre, Central Analytical and Applied Research Unit, Sultan Qaboos University, Oman; Department of Botany, N.N. Saikia College, Titabar, Jorhat, Assam, India; E-mails: sanket@squ.edu.om; hemens02@yahoo.co.in
}

indigenous or exogenous microorganisms introduced into the contaminated site. Indigenous microorganisms found in polluted environments hold the key to overcoming the majority of the barriers to pollutant biodegradation and bioremediation. Understanding bioremediation and its effectiveness is advancing at a rapid pace, with molecular biology approaches for determining the presence and expression of key genes involved in microbial processes becoming available $[9,10]$.

The thematic issue "Micropollutants in the Environment: Challenges and Bioremediation Strategies," through review articles contributed by environmental biotechnology experts, offers a glimpse of current updates on applications of microbial cells and enzymes for bioremediation of dyes and other chemicals and the synthesis of high-value fine chemicals and pharmaceuticals; a case study of $\mathrm{SO}_{2}$ industrial emission by biomonitoring and regional post-mining hot-spots; toxicity of nanomaterials; pesticide-induced DNA damage and genetic polymorphisms; energy generation by microbial fuel cells and wastewater treatment; possible algal applications for sustainable pollution mitigation. The thematic issue consists of seven review articles contributed by authors from Poland, India, Oman, and Sri Lanka.

International acclaim has been given to enzyme technology for the removal of toxic organic compounds [11]. Nitriles are one such organic compound of interest, having the cyanide group, which is naturally present in fruit pits, cabbage, cauliflower, and sprouts, as well as intermediate byproducts and waste products of various chemical, pharmaceutical, and agricultural industries. Nitrile converting enzymes, i.e., nitrilases, have been reported in microorganisms and plants, which are of interest to organic synthesis scientists and entrepreneurs [12]. A review paper by Bhatt et al. reported the current status and the future of nitrile catalysis using key nitrilases enzymes and their biotechnological impact. Sulphur is an important microelement required for plant growth, but at higher concentrations, it can be detrimental. The last century 
recorded rising levels of high $\mathrm{SO}_{2}$ concentrations due to the combustion of fossil fuels, open-pit lignite and sulphur borehole mining, and wet deposition from acid rains, which exacerbated forest dieback and regional scale ecosystem contamination [13]. The monitoring and assessment, as well as their removal from the environment, are critical. A review paper contributed by Likus-Cieślik and Pietrzykowski highlighted this issue and a case study of current $\mathrm{SO}_{2}$ industrial emission by biomonitoring and regional post-mining hot-spots. Chemical dyes are one of the widely used chemicals in different sectors, and it is well known as recalcitrant compounds posing a serious ecotoxic hazard as well as the risk of bioaccumulation, potentially affecting flora and fauna. While traditional treatment processes are reported, biological processes are touted to be a cost-effective alternative method for the decolorization and degradation of such synthetic dyes $[14,15]$. A review paper by Rane and Joshi reported provided insight on biodecolorization and biodegradation of dyes. Nanomaterials have become widely accepted for use in a variety of fields, including agriculture, biomedical, and the environment $[16,17]$. However, the release and accumulation of such nanomaterials during different applications can have adverse effects on plants and animals. A review paper by Adassooriya and Madanayake discusses the phytotoxic effects of nanomaterials in the field of agriculture. Human exposure is unavoidable as a result of the dramatic increase in pesticide applications, whether through environmental or occupational exposure. It could lead to several adverse health effects via a variety of mechanisms, including DNA damage, mutations, and cancer. It is imperative that non-toxic pesticide derivatives must be developed for health, safety, and the environment [18]. However, the degree of toxicity varies between individuals due to the effect of genetic polymorphisms on xenobioticmetabolizing enzymes that modulate the biological process [19]. A review by Bello Usman et al. aims at providing the summary of recent studies on genetic polymorphisms and pesticide-induced DNA damage. Concerns about public health and the demand for clean energy drive the development of agricultural waste or wastewater-based Microbial Fuel Cells (MFC) [20, 21]. Wastewater treatment and bioelectricity generation at the same time provide numerous environmental benefits. Nonetheless, it is also important to understand the challenges associated with MFC technology in order to scale up the wastewater-based MFC. The review paper by Venkatramanan et al. critically examined the processes, applications, challenges, and opportunities of wastewater-based MFCs. Due to their unique photosynthetic ability and simple growth requirements, algae can be grown with simple components such as $\mathrm{CO}_{2}$, sunlight, and simple mineral nutrients, making them a potential candidate for use as a pollution mitigator $[4,22]$. A review paper by Tripathy et al. discusses the present and future prospect of algae as a potential candidate for sustainable pollution mitigation.

Although the current thematic issue covered a few of those important aspects, the guest editors firmly believe that the collection of review articles in this thematic issue will be interesting and useful to the scientific community.

\section{ACKNOWLEDGEMENTS}

We wish to thank all the expert authors for their contribution and all the reviewers, for their critical insight and timely reviews of manuscripts, without which this thematic issue was not possible. SJ and HS would also like to kindly acknowledge the support provided by Sultan Qaboos University, Oman, and N. N. Saikia College, India, respectively.

\section{REFERENCES}

[1] Aemig Q, Hélias A, Patureau D. Impact assessment of a large panel of organic and inorganic micropollutants released by wastewater treatment plants at the scale of France. Water Res 2021; 188116524 [http://dx.doi.org/10.1016/j.watres.2020.116524] [PMID: 33099267]

[2] Barnes JL, Zubair M, John K, Poirier MC, Martin FL. Carcinogens and DNA damage. Biochem Soc Trans 2018; 46(5): 1213-24. [http://dx.doi.org/10.1042/BST20180519] [PMID: 30287511]

[3] Islam NF, Sarma H, Prasad MN. Emerging disinfection by-products in water: novel biofiltration techniques. Disinfection by-products in drinking water. Elsevier 2020; pp. 109-35.

[http://dx.doi.org/10.1016/B978-0-08-102977-0.00005-6]

[4] Sarma H, Lee WY. Bacteria enhanced lignocellulosic activated carbon for biofiltration of bisphenols in water. Environ Sci Pollut Res Int 2018; 25(18): 17227-39.

[http://dx.doi.org/10.1007/s11356-018-2232-7] [PMID: 29808400]

[5] Luo X, Yang J. A survey on pollution monitoring using sensor networks in environment protection. J Sens 2019; 2019 [http://dx.doi.org/10.1155/2019/6271206]

[6] Livingstone DR. Biotechnology and pollution monitoring: Use of molecular biomarkers in the aquatic environment. J Chem Technol Biotechnol 1993; 57(3): 195-211.

[http://dx.doi.org/10.1002/jctb.280570302]

[7] Sarma H, Sonowal S, Prasad MNV. Plant-microbiome assisted and biochar-amended remediation of heavy metals and polyaromatic compounds - a microcosmic study. Ecotoxicol Environ Saf 2019; 176: $288-99$.

[http://dx.doi.org/10.1016/j.ecoenv.2019.03.081] [PMID: 30947032]

[8] Joshi SJ, Deshmukh A, Sarma H, Eds. Biotechnology for sustainable environment. Springer Singapore 2021.

[http://dx.doi.org/10.1007/978-981-16-1955-7]

[9] Andreoni V, Gianfreda L. Bioremediation and monitoring of aromaticpolluted habitats. Appl Microbiol Biotechnol 2007; 76(2): 287-308. [http://dx.doi.org/10.1007/s00253-007-1018-5] [PMID: 17541581]

[10] Sarma H, Joshi SJ. Metagenomics combined with Stable Isotope Probe (SIP) for the discovery of novel dehalogenases Producing Bacteria. Bull Environ Contam Toxicol 2020; 1-7.

[http://dx.doi.org/10.1007/s00128-020-03004-7] [PMID: 32978646]

[11] Karigar CS, Rao SS. Role of microbial enzymes in the bioremediation of pollutants: a review. Enzyme Res 2011; 2011805187

[http://dx.doi.org/10.4061/2011/805187] [PMID: 21912739]

[12] Gong JS, Lu ZM, Li H, Shi JS, Zhou ZM, Xu ZH. Nitrilases in nitrile biocatalysis: recent progress and forthcoming research. Microb Cell Fact 2012; 11(1): 142 .

[http://dx.doi.org/10.1186/1475-2859-11-142] [PMID: 23106943]

[13] Carbajo JM, Maraver F. Sulphurous mineral waters: New applications for health. Evid Based Complement Alternat Med 2017; 20178034084 [http://dx.doi.org/10.1155/2017/8034084] [PMID: 28484507]

[14] Methneni N, Morales-González JA, Jaziri A, Mansour HB, FernandezSerrano M. Persistent organic and inorganic pollutants in the effluents from the textile dyeing industries: Ecotoxicology appraisal via a battery of biotests. Environ Res 2021; 196110956

[http://dx.doi.org/10.1016/j.envres.2021.110956] [PMID: 33675797]

[15] Srinivasan S, Sadasivam SK. Biodegradation of textile azo dyes by textile effluent non-adapted and adapted Aeromonas hydrophila. Environ Res 2021; 194110643

[http://dx.doi.org/10.1016/j.envres.2020.110643] [PMID: 33385387]

[16] Rane AN, Geetha SJ, Joshi SJ. Biosurfactants: Production and role in synthesis of nanoparticles for environmental applications. Biosurfactants for a Sustainable Future: Production and Applications in the Environment and Biomedicine 2021; 183-206. [http://dx.doi.org/10.1002/9781119671022.ch9]

[17] Sarma H, Joshi S, Prasad R, Jampilek J, Eds. Biobased nanotechnology for green applications. Springer International 
Publishing 2021.

[http://dx.doi.org/10.1007/978-3-030-61985-5]

[18] Kaur Gill JP, Singh S, Sethi N, et al. Efficient synthesis and characterization of non-toxic glyphosate derivatives as eco-friendly herbicides. Cur Res Green Sustain Chem 2021; 100100 [http://dx.doi.org/10.1016/j.crgsc.2021.100100]

[19] Damalas CA, Eleftherohorinos IG. Pesticide exposure, safety issues, and risk assessment indicators. Int J Environ Res Public Health 2011; 8(5): 1402-19.

[http://dx.doi.org/10.3390/ijerph8051402] [PMID: 21655127]

[20] Ardakani MN, Gholikandi GB. Microbial Fuel Cells (MFCs) in integration with Anaerobic Treatment Processes (AnTPs) and
Membrane Bioreactors (MBRs) for simultaneous efficient wastewater/sludge treatment and energy recovery - A state-of-the-art review. Biomass Bioenergy 2020; 141105726

[http://dx.doi.org/10.1016/j.biombioe.2020.105726]

21] Rojas Flores S, Naveda RN, Paredes EA, et al. Agricultural wastes for electricity generation using microbial fuel cells. Open Biotechnol J 2020; 14(1): 52-8.

[http://dx.doi.org/10.2174/1874070702014010052]

[22] Thakare M, Sarma H, Datar S, et al. Understanding the holistic approach to plant-microbe remediation technologies for removing heavy metals and radionuclides from soil. Cur Res Biotech 2021; 3: 84-98.

[http://dx.doi.org/10.1016/j.crbiot.2021.02.004]

(C) 2021 Joshi \& Sarma.

This is an open access article distributed under the terms of the Creative Commons Attribution 4.0 International Public License (CC-BY 4.0), a copy of which is available at: https://creativecommons.org/licenses/by/4.0/legalcode. This license permits unrestricted use, distribution, and reproduction in any medium, provided the original author and source are credited. 